Research Article

\title{
A Real-time Optoelectronic Device in Screening of Precancerous Cervical Lesion
}

\author{
Deteksi Dini Lesi Prakanker dengan Perangkat Optoelektronik Real-Time
}

\author{
Rizky Rahmadhany, Junita Indarti \\ Department of Obstetrics and Gynecology \\ Faculty of Medicine University of Indonesia/ \\ Dr. Cipto Mangunkusumo National Hospital \\ Jakarta
}

\begin{abstract}
Objective: To obtain the diagnostic values of optoelectronic device for screening of precancerous cervical lesions.

Method: We performed a diagnostic study with cross sectional design. Subjects were recruited from Dr. Cipto Mangunkusumo Hospital, from February until December 2013. Subjects were enrolled based on consecutive sampling until the minimum sample was achieved (60 samples).

Result: During the study period, 60 patients were enrolled. Sensitivity, specificity, positive predictive value, and negative predictive value of the optoelectronic device were $76 \%, 95 \%, 96 \%$, and $64 \%$, respectively. We also investigated diagnostic values of other screening methods, namely citology and colposcopy. Sensitivity and specificity of liquid based cytology were $83 \%$ and $63 \%$ respectively. The combination of optoelectronic device and liquid based cytology increased the sensitivity to $92.8 \%$. Meanwhile, sensitivity and specificity of colposcopy were $88 \%$ and 58\%, respectively. Based on Altman criteria, kappa value for optoelectronic device with cytology was 0.35 (fair) and optoelectronic device with colposcopy was 0.45 (moderate).
\end{abstract}

Conclusion: A real-time optoelectronic device might be used as an alternative method in early detection of precancerous cervical lesions, either as a single method or combined with liquid based cytology.

[Indones J Obstet Gynecol 2015; 2: 117-120]

Keywords: diagnostic values, optoelectronic device, precancerous cervical lesions

\begin{abstract}
Abstrak
Tujuan: Untuk mengetahui nilai diagnostik perangkat optoelektronik dalam mendeteksi lesi prakanker serviks.

Metode: Studi ini merupakan studi diagnostik dengan desain potong lintang. Subjek penelitian direkrut dari Rumah Sakit Dr. Cipto Mangunkusumo, Jakarta, Indonesia dari bulan Februari hingga Desember 2013. Sampel dikumpulkan dengan metode pengambilan sampel secara konsekutif hingga jumlah minimum sampel tercapai (60 sampel).

Hasil: Selama periode penelitian, didapatkan 60 pasien yang ikut serta dalam penelitian ini. Sensitivitas, spesifisitas, nilai prediktif positif, dan nilai prediktif negatif dari perangkat optoelektronik yaitu 76\%, 95\%, 96\%, dan 64\% berturut-turut. Sensitivitas dan spesifisitas sitologi berbasis cairan yaitu $83 \%$ dan 63\% secara berturut-turut, kombinasi dengan perangkat optoelektronik meningkatkan sensitivitas menjadi 92,68\%. Sedangkan sensitivitas dan spesifisitas kolposkopi yaitu 88\% dan 58\% secara berturut-turut. Nilai kappa berdasarkan kriteria Altman perangkat optoelektronik dengan sitologi yaitu 0,35 (cukup) dan dengan kolposkopi yaitu 0,45 (sedang).
\end{abstract}

Kesimpulan: Perangkat optoelektronik yang hasilnya didapatkan saat itu juga dapat menjadi metode alternatif dalam deteksi dini lesi prakanker serviks, baik sebagai metode tunggal maupun kombinasi dengan sitologi berbasis cairan.

[Maj Obstet Ginekol Indones 2015; 2: 117-120]

Kata kunci: lesi prakanker serviks, nilai diagnostik, perangkat optoelektronik

Correspondence: Junita Indarti, Department of Obstetrics and Gynecology Faculty of Medicine University of Indonesia/ Dr. Cipto Mangunkusumo Hospital, Jalan Diponegoro No. 71, Jakarta, Indonesia, 10430

Telephone: 0213100695, e-mail: junita.indarti@yahoo.com

\section{INTRODUCTION}

Based on Globocan data in 2012, cervical cancer is the fourth most common malignancy worldwide after breast, colorectal, and gastric cancer, with an estimated 528,000 new cases, and almost one-third found in South - East Asian countries. Approximately 266,000 deaths from cervical cancer $(7.5 \%$ of all female cancer mortality), and about $87 \%$ of cervical cancer mortality occur in developing countries. $^{1}$
Around 20,928 new cases of cervical cancer are diagnosed each year in Indonesia, with an agestandardized incidence of 17.3/100,000 women per year. ${ }^{2}$ Aziz et al stated that cervical cancer accounts for $75 \%$ of all gynecological cancer in an Indonesian academic hospital, with the majority presenting in advanced stages. ${ }^{3}$ Based on registry data of Indonesian Society of Gynecology Oncology (2013), there were 446 new cervical cancer cases in Dr. Cipto Mangunkusumo Hospital, Jakarta, Indo- 
nesia in 2013 , and $76.68 \%$ of them presented to the health service in advanced stages. ${ }^{4}$

In the early stages, cervical cancer has no specific or typical signs and symptoms. Therefore, every woman is advised to undergo screening for cervical cancer as early as possible, using the method of Papanicolaou (Pap) test cytologic examination. ${ }^{5}$ Even though the effectivity of Pap test as a screening test has not been proven with a randomized test, it has been well known to effectively decrease the incidence and mortality rate of cervical cancer in developed countries. In the United States, Pap test succeeded to change cervical cancer from the leading cause of female death to an infrequent disease, decreasing the incidence by about $75 \%$ since Pap test was found 40 years ago. However, only few countries possess adequate infrastructure and human resources to perform cervical cancer screening program, leading to the high number of cervical cancer cases in some countries, especially in developing countries. ${ }^{6}$ In Indonesia, there are more than 13,000 islands but fewer than 300 pathologists are available, with most of them centered in urban areas. Therefore a screening method is needed, which might be as effective as Pap test or liquid based cytology (LBC) but does not require evaluation of specimens.

Recently, biophysics has emerged as a new method in the diagnosis and prevention of cervical cancer. Due to its low false positive and false negative results, biophysics method is a promising screening method for cervical cancer. Truscreen is a novel optoelectronic device utilizing this method as a screening tool for the detection of precancerous cervical lesions. This real time device uses low-level electrical and optical signals to scan the cervix. The response will be measured by computer-based expert system software, which will classify the tissue response by comparing the signals with those stored in a computer database representative of the range of cervical tissue types. ${ }^{7}$ Because this method is automated, it might be considered for use in developing countries where the pathologists are few and are not widespread throughout the area, and can even be used by nurses or midwives. ${ }^{8}$

There have been no studies on the use of optoelectronic device in detecting precancerous cervical lesions in Indonesia. As it seems promising and does not heavily rely on the operator or pa- thologists, we tried to investigate its diagnostic values in detecting precancerous cervical lesions.

\section{METHODS}

We performed a diagnostic study utilizing cross sectional design. The subjects were recruited from Dr. Cipto Mangunkusumo Hospital, Jakarta, Indonesia during the period of February until December 2013. Cervical cancer screening methods were performed in all subjects in the form of optoelectronic device (TruScreen, Polartechnics Limited, Sydney, Australia), liquid based cytology, and colposcopy followed by targeted biopsy. Human Papilloma Virus (HPV) DNA test was performed only on several subjects due to its high cost.

The patient presenting to the outpatient clinic of Dr. Cipto Mangunkusumo National Hospital in the period above, who desired to undergo cervical cancer screening or referred from other centers (midwives, public health care, OBGYN, general practitioner) with suspected precancerous cervical lesion were included in this study. Patients refusing to join this study, those with suspected or confirmed cervical cancer, and confirmed invasive carcinoma on biopsy were excluded.

The samples were enrolled based on consecutive sampling method until the minimum number of samples were achieved (60 samples). All patients gave their consent after being informed by the investigators.

Data were analyzed using SPSS 21.0. Abnormal results of optoelectronic device, biopsy, cytologic examination, colposcopy and HPV DNA examination will be showed descriptively. We analyzed diagnostic values for optoelectronic device, LBC, and colposcopy compared to the gold standard, anatomic pathology biopsy. To understand the similarity and comparison between two methods of cervical precancerous lesion screening, we determine the kappa value between optoelectronic device with LBC and colposcopy.

\section{RESULTS}

During the research period, 66 patients were recruited, and 6 patients were excluded due to invasive carcinoma result based on their biopsy. Subject characteristics are shown below. 
Table 1. Subject Characteristics.

\begin{tabular}{lcc}
\hline \hline \multicolumn{1}{c}{ Characteristic } & & Data (n=60) \\
\hline Age & (mean \pm SD) & $42 \pm 9.18$ \\
History of Contraception Use & No history & $10(16.7 \%)$ \\
& IUD & $18(30 \%)$ \\
& DMPA & $15(35 \%)$ \\
& Oral contraceptives & $8(13.3 \%)$ \\
Level of Education & Sterilization & $9(15 \%)$ \\
& No formal education & $1(1.7 \%)$ \\
& Primary school & $10(16.7 \%)$ \\
Parity & Middle school & $27(45 \%)$ \\
& High school & $22(36.7 \%)$ \\
\hline \hline
\end{tabular}

There were 32 patients (53\%) with abnormalities based on the optoelectronic device, 41 patients $(68,3 \%)$ with precancerous cervical lesion on biopsy, 44 patients $(73,3 \%)$ with abnormal colposcopy result, and 41 patients $(63,3 \%)$ with abnormal LBC result. From 41 patients who had confirmed cervical precancerous lesion on biopsy, 18 (44\%) had low grade squamous intraepithelial lesion (CIN 1) and 23 (56\%) had high grade squamous intraepithelial lesion (CIN 2 and 3, carcinoma in situ).

Sensitivity, specificity, positive predictive value, and negative predictive value of optoelectronic device were $76 \%, 95 \%, 96 \%$, and $64 \%$, respectively. We also investigated the diagnostic values of other screening methods, namely cytology and colposcopy. Sensitivity and specificity of LBC were $83 \%$ and $63 \%$, respectively. Sensitivity and specificity of colposcopy were $88 \%$ and $58 \%$, respectively. The combination of optoelectronic device and LBC increased the sensitivity to $92,8 \%$.

To evaluate inter-rater agreement, we analyzed the Kappa value. Kappa value for optoelectronic device with cytology was 0.35 (fair) and for optoelectronic device with colposcopy was 0.45 (moderate). These values mean optoelectronic device is quite similar or might be comparable with cytology and colposcopy in screening of precancerous cervical lesion.

\section{DISCUSSION}

In this study, we excluded cases with confirmed cervical cancer as proven by biopsy or clinical examination, because the objective of our study is to investigate the diagnostic values of optoelectronic device in detecting cervical pre-cancerous lesion as early as possible so that the patient might be treated properly before the development of cervical cancer.

In our study, the number of abnormal optoelectronic device test results was quite high (> 50\%), indicating the presence of precancerous cervical lesion, either low grade squamous intraepithelial lesion (LGSIL) or high grade squamous intraepithelial lesion (HGSIL). The sensitivity of optoelectronic device in detecting precancerous cervical lesion in our study was $76 \%$, which was in line with the study by Lee et al. ${ }^{9}$ They concluded that Truscreen has a sensitivity of $75.8 \%$ in detecting CIN 1 and 77.3\% for CIN 2/3, with 85.1\% specificity. In a multicenter study of 651 subjects by Singer et al, the sensitivity of Truscreen was reported to be $67 \%$ for CIN 1 and $70 \%$ for CIN $2 / 3$. $^{7}$ However, Allameh and Long reported lower sensitivity; $46.9 \%$ and $67.4 \%$, respectively. 8,10

We observed that the sensitivity of this device in detecting LGSIL (88.24\%) was higher than HGSIL (96\%), in contrast to the previous study, which was $67 \%$ versus $70 \% .^{7}$ Different sampling methods in both studies might be the cause of this difference. Surprisingly, we observed a high specificity for optoelectronic device, which was even higher than LBC and colposcopy. This result was supported by previous studies conducted by Lee and Lim, who reported a specificity of $85.1 \%$ and 81.4 , respectively. ${ }^{9,11}$

Pruski et al reported the area under the ROC curve of optoelectronic device to detect HGSIL and squamous cell carcinoma was 0.88 , which indicates a high diagnostic value. ${ }^{12}$ 
We attempted to evaluate whether optoelectronic device was equal or more reliable in comparison to other commonly known methods of cervical cancer screening such as LBC and colposcopy. Based on inter-rater agreement analysis, kappa value for optoelectronic device with cytology was 0.35 (fair) and optoelectronic device with colposcopy was 0.45 (moderate). Therefore, we can conclude that optoelectronic device was comparable with $\mathrm{LBC}$ and colposcopy in detecting precancerous cervical lesion.

There are some advantages in performing optoelectronic device to detect precancerous cervical lesion, specifically in Indonesia. Automated processed result of this device will decrease the risk of human error and not having to rely on laboratory examinations, immediate results (real time examination) will reduce the number of patient visits, shortened screening-treatment timeline, reduced loss of follow-up, and finally, decreased cost in cervical cancer screening programs.

\section{CONCLUSION}

A real-time optoelectronic device might be used as an alternative method in early detection of precancerous cervical lesions, either as a single method or combined with liquid based cytology.

\section{CONFLICT OF INTEREST}

No potential conflict of interest relevant to this article was reported.

\section{REFERENCES}

1. International Agency for Research on Cancer. Globocan 2012: Estimated cancer incidence, mortality, and prevalence worldwide in 2012. [Online]. Last updated 2012 Available from: URL: globocan.iarc.fr/Pages/fact_sheets_ cancer.aspx

2. Bruni L, Barrionuevo-Rosas L, Serrano B, et al. ICO Information Centre on HPV and Cancer (HPV Information Centre). Human Papillomavirus and related diseases in Indonesia. Summary Report 2014-03-17.

3. Aziz MF. Gynecological cancer in Indonesia. J Gynecol Oncol 2009; 20(1): 8-10.

4. Indonesian Society for Gynecologic Oncology. Cancer Registration Information System. [Online]. Last updated 2013. Available from: URL:http://www.inasgo.org/ (accessed 05/ 02/2014)

5. Katz IT, Wright AA. Preventing cervical cancer in the developing world. N Eng J Med 2006; 354: 1110.

6. Aziz MF, Andrijono, Saifuddin AB. National reference on gynecologic oncology (Buku acuan nasional onkologi ginekologi). $1^{\text {st }}$ ed. Jakarta: Yayasan Bina Pustaka Sarwono Prawirohardjo; 2006.

7. Singer A, Coppleson M, Canfell K, et al. A real time optoelectronic device as an adjunct to the Pap smear for cervical screening: a multicenter evaluation. Int J Gynecol Cancer 2003; 13(6): 804-11.

8. Allameh T, Khanjani S, Mohammadizadeh F, et al. Diagnostic value of the combination of TruScreen and Pap smear in screening cervical epithelial lesions: Does it add advantages over the Pap smear alone? Open J Obstet Gynecol 2013; 3: 341-6.

9. Lee SJ, Bae JH, Kim JH, et al. A real-time optoelectronic device in screening of cervical intraepithelial neoplasia. J Women's Med 2009; 2(1): 23-8.

10. Long S, Lei W, Feng Y, et al. The feasibilities of TruScreen for primary cervical cancer screening: a self-controlled study. Arch Gynecol Obstet 2013; 288(1): 113-8.

11. Lim HS, Kim MJ, Park KE, et al. The efficacy of a real-time optoelectronic device as a diagnostic tool of over cervical intraepithelial neoplasia 1 lesion. Korean J Obstet Gynecol 2010; 53(10): 888-93.

12. Pruski D, Przylbylski M, Kedzia W, et al. Optoelectronic method for detection of cervical intraepithelial neoplasia and cervical cancer. Opto-electronics Rev 2011; 19(4): 478-85. 